\title{
Serological Evidence of Human Coinfection by Brazilian Spotted Fever and Bartonellosis
}

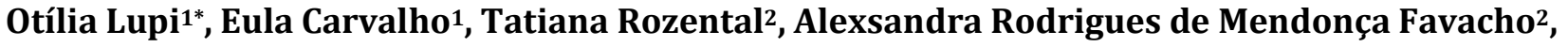 \\ Elba Regina Sampaio de Lemos' ${ }^{2}$, Patricia Brasil ${ }^{1}$ \\ ${ }^{1}$ Laboratório de Doenças Febris Agudas, Instituto Nacional de Infectologia Evandro Chagas (INI), \\ Fundação Oswaldo Cruz (FIOCRUZ), Rio de Janeiro, Brazil \\ ${ }^{2}$ Laboratório de Hantaviroses e Rickettsioses, Instituto Oswaldo Cruz (IOC), Fundação Oswaldo Cruz, (FIOCRUZ), Rio de Janeiro, Brazil \\ Email: *otilia.lupi@ini.fiocruz.br, eula.carvalho@ini.fiocruz.br, rozental@ioc.fiocruz.br, afavacho@ioc.fiocruz.br, \\ elemos@ioc.fiocruz.br, patricia.brasil@ini.fiocruz.br
}

How to cite this paper: Lupi, O., Carvalho, E., Rozental, T., de Mendonça Favacho, A.R., de Lemos, E.R.S. and Brasil, P. (2016) Serological Evidence of Human Coinfection by Brazilian Spotted Fever and Bartonellosis. International Journal of Clinical Medicine, 7, 766-770.

http://dx.doi.org/10.4236/ijcm.2016.711083

Received: September 29, 2016

Accepted: November 26, 2016

Published: November 29, 2016

Copyright $\odot 2016$ by authors and Scientific Research Publishing Inc. This work is licensed under the Creative Commons Attribution International License (CC BY 4.0).

http://creativecommons.org/licenses/by/4.0/

\begin{abstract}
Brazilian spotted fever and bartonellosis are zoonotic, emerging and under diagnosed diseases. Pets may be co-infected by multiple pathogens and become transmissions sources to humans. The study reports the first case of active co-infection by Brazilian spotted fever and bartonellosis based on serological evidence. The authors aim to demonstrate the importance of performing systematic syndromic investigations on nonspecific febrile syndromes, guided by the epidemiological history and considering the possibility of co-infection by zoonosis sharing the same ecological niche.
\end{abstract}

\section{Keywords}

Rickettsia rickettsii, Bartonella henselae, Brazilian Spotted Fever, Bartonellosis, Co-Infection

\section{Introduction}

Brazilian Spotted Fever (BSF) and bartonellosis are zoonotic diseases respectively considered reemerging and emerging. They are transmitted to humans by accident and are generally under diagnosed.

BSF, described in Brazil since the 1920s, is caused by Rickettsia rickettsii, and ticks are its vectors and reservoirs, especially those from Amblyomma sculptum species (from the Amblyomma cajennense complex), although other infected species may participate in its transmission [1]. It has wide geographical distribution with limited outbreaks in the Brazilian southeastern and southern regions, and in some locations in the midwest, northeast and north regions [2]. Its distribution is seasonal, between May and 
October. On average, 55 cases are annually recorded in Brazil [3] and lethality ranges from $20 \%$ to $30 \%$ [2] [3]. The initial clinical presentation is nonspecific and may progress to sepsis and death mainly due to late diagnosis and consequent delay in the introduction of the specific treatment [1] [2] [3] [4].

Bartonellosis is caused by species from the Bartonella genus. The $B$. henselae species is the main pathogen for humans and it is often transmitted by scratching, biting, licking, or simple contact with cat's fleas and other ectoparasites. In addition to cats, several other mammals may be reservoir and vector. The species has worldwide distribution and seasonality period between January and July [5] [6]. Its incidence is of 3.7/100.000 in habitants. Most cases are benign and self-limiting, but the disease may progress to prolonged bacteremia, get worse and lead to cutaneous, hepatic or splenic vasoproliferative effects, especially in immunocompromised patients [5].

Veterinary studies demonstrate that animals, especially dogs, may be co-infected by multiple Proteobacterium pathogens, and become transmission sources to humans who manipulate them. Co-infection by $R$. rickettsii and by some Bartonella species, except for $B$. henselae, had been reported [7] [8]. However, B. henselae had been identified in domestic dog fleas [9] [10]. Additionally, there are records of human co-infection by $R$. rickettssii and Ehrlichia chaffeensis [11]. Kordich performed a serological survey and found antibodies to $B$. henselae and $R$. rickettsii on healthy dog breeder [7]. Despite the finding could not be correlated with the presence of simultaneous infectious syndrome, the co-infection possibility could be taken under consideration. Nevertheless, literature has no report on human active co-infection by BSF and bartonellosis.

The current study aims to report the first human case with serological evidence of active co-infection by $R$. rickettsii and B. henselae, recorded in Rio de Janeiro, Brazil. It is an alert to health professionals about the possibility of co-infection, the impact of this event on the research algorithm, the following up of complications and the empirical choice for specific therapies.

\section{Case Report}

MAJD, female, 47 years old, lived in São João de Meriti (metropolitan region of Rio de Janeiro/Brazil). She was previously healthy with nocomorbidities. In April 2014, she started presenting fever, chills, occipital headache, myalgia, hyporexia and hypogeusia. The patient sought the primary care unit several times between the $2^{\text {nd }}$ and $13^{\text {th }}$ day of the disease, time when the diagnostic hypothesis of dengue was considered and its supportive treatment was introduced. Between the $6^{\text {th }}$ and $10^{\text {th }}$ day of the disease, she presented aqueous diarrhea and vomiting. Since fever persisted, the patient was referred to the National Institute of Infectious Diseases in the $14^{\text {th }}$ day of the disease. She reported the habit of collecting dogs and cats often parasitized by ectoparasites, which were abandoned. She also reported that one dog and one cat were being treated for "tick disease" and "infectious disease without etiology", respectively. She took care of her pets without using personal protective equipment. At the $14^{\text {th }}$ day she was febrile $\left(38^{\circ} \mathrm{C}\right)$ and hemodynamically stable, without cutaneous rash or lymphadenopathy. La- 
boratory tests performed in the $14^{\text {th }}$ day showed increased C-reactive protein with no others hematological, renal and hepatic changes. Previous laboratory tests showed leukocytosis without deviation in the $2^{\text {nd }}$ day of the disease and thrombocytopenia between the $3^{\text {rd }}$ and $13^{\text {th }}$ day of the disease. The diagnostic hypothesis of zoonosis: BSF, leptospirosis or bartonellosis was consideration and specific tests were performed. In addition, dengue, viral hepatitis and other nonspecific bacterial infections investigated were complemented. Empirical treatment with doxycycline was immediately introduced at the dose of $200 \mathrm{mg} /$ day. The patient evolved with defervescence and clinical improvement within 48 hours after started the antibiotic, and was discharged within 60 days (Figure 1). All test results-except for the BSF and bartonellosis serological tests-were negative, including the molecular analysis (PCR) for both Proteobacteria. Indirect immunofluorescence presented IgG antibody title of $1 / 512$ for $R$. rickettsii and 1/128 for $B$. henselae on the $15^{\text {th }}$ day of the disease, and on the $50^{\text {th }}$ day the $\operatorname{IgG}$ antibody title was $1 / 1024$ for $R$. rickettsii and 1/256 for B. henselae (Table 1).

\section{Discussion}

The patient presented initially a nospecific febrile syndrome. There was a delay in diagnosis and treatment due to the relative unawareness about the occurrence of the zoonosis among humans. Additionally the overlap of hyperendemic diseases, such as Dengue, has also been a frequent confounder factor. Epidemiological history suggests that the infection has been acquired through the unprotected handling of her own pets, some of them known to be sick. The delay in the first sampling and effective treatment can in part explain our inability to demonstrate the perfect seroconversion and the
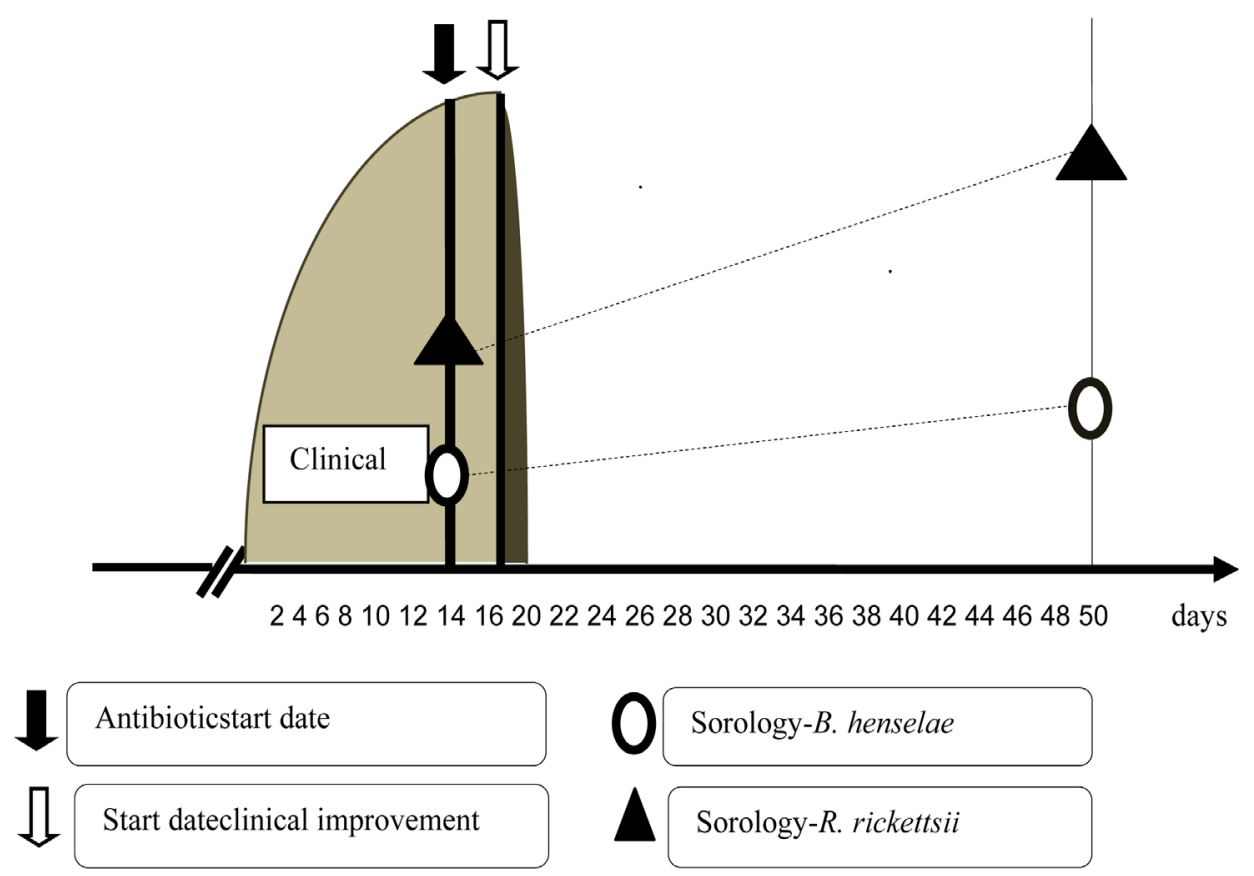

Sorology-B. henselae

Sorology- $R$. rickettsii

Figure 1. Clinical and laboratory time evolution. 
Table 1. Representation of the relevant laboratory tests.

\begin{tabular}{|c|c|c|c|c|c|c|c|c|}
\hline & \multirow{2}{*}{$\begin{array}{c}\text { Disease } \\
\text { time in } \\
\text { days }\end{array}$} & \multicolumn{4}{|c|}{ Complete Blood Count } & \multirow{2}{*}{$\begin{array}{c}\text { CRP } \\
(\mathrm{mg} / \mathrm{dL})\end{array}$} & \multirow{2}{*}{$\begin{array}{c}\mathrm{Rr} \\
(\mathrm{IgG})\end{array}$} & \multirow{2}{*}{$\begin{array}{c}\mathrm{Bh} \\
(\mathrm{IgG})\end{array}$} \\
\hline & & $\mathrm{Hb}(\mathrm{g} / \mathrm{dL})$ & $\mathrm{Ht}(\%)$ & Leuk $\left(\mathrm{mm}^{3}\right)$ & Plat $\left(\mathrm{mm}^{3}\right)$ & & & \\
\hline \multirow{6}{*}{ HUPC } & 2nd & 13.8 & 42.0 & 15,400 & 180,000 & - & - & - \\
\hline & $3 r d$ & 12.6 & 37.8 & 8,200 & 82,000 & - & - & - \\
\hline & 4 th & 11.7 & 34.7 & 7,200 & 53,000 & - & - & - \\
\hline & 6 th & 11.9 & 35.6 & 7,000 & 57000 & - & - & - \\
\hline & 7 th & 12.2 & 36.1 & 7,900 & 101,000 & - & - & - \\
\hline & 13 th & 12.2 & 35.1 & 8,100 & 65,000 & - & - & - \\
\hline \multirow{3}{*}{ INI } & 14 th & 11.6 & 36.3 & 9,140 & 209,000 & 8.11 & - & - \\
\hline & 15 th & 11.8 & 36.4 & 6,500 & 113,000 & 0.45 & $1: 512$ & $1: 128$ \\
\hline & 50 th & - & - & - & - & - & $1: 1020$ & $1: 256$ \\
\hline
\end{tabular}

Nomenclature and benchmarks: HUPC = Health Unit Primary Care; INI = National Institute of Infectious Diseases; $\mathrm{Hb}=$ Hemoglobin $(11-16 \mathrm{~g} / \mathrm{dL})$. Ht = Hematocrit $(34-45 \mathrm{~g} / \mathrm{dL})$; Leuk = leukocytes $\left(4000-10,000 \mathrm{~mm}^{3}\right)$; Plat = Platelets $\left(150,000-450,000 \mathrm{~mm}^{3}\right)$. CRP $=$ C-reative protein $(0-0.3 \mathrm{mg} / \mathrm{dL}) ; \mathrm{Rr}=$ Rickettsii rickettsii. $\mathrm{Bh}=$ Bartonellahenselae; $\mathrm{IgG}=$ Immunoglobulin $G$.

negative specific Polymerase Chain Reaction (PCR). The possibility of $R$. rickettsii and $B$. henselae molecular detection is higher in the early stages of the disease, with greater sensitivity in severe and fatal cases. Furthermore, the excellent therapeutic response, as well as the epidemiological history, reinforces the BSF and bartonellosis diagnostic. Usually serology is an essential and largely available method to laboratory confirmation for both zoonosis, however, it depends on the opportunity of the investigation [1] [4] [12].

The authors of the current study intend, by means of this report, to emphasize the importance of performing a syndromic investigation strongly guided by the epidemiological history, especially in an undifferentiated febrile syndrome. In addition, the possibility of co-infection by Proteobacteria zoonosis which shares the same ecological niche must be considered, and this possibility needs to be included in diagnostic algorithm for the choice of the most appropriate antimicrobial medication in order to decrease morbidity and mortality caused by the zoonosis.

\section{Acknowledgements}

The Laboratory of ESL is supported by the Conselho Nacional de Desenvolvimento Científico e Tecnológico (CNPq) through a Research Fellowship and by the Fundação Carlos Chagas Filho de Amparo à Pesquisa do Estado de Rio de Janeiro (Faperj).

\section{Financial Support Information}

The present study received no specific financial support.

\section{Conflict of Interest}

The authors declare that there is no conflict of interest. 


\section{Consent}

Written consent was obtained from the patient under a research project approved by the Ethic Committees of IPEC/FIOCRUZ: "Detecção de formas não usuais de dengue a partir da vigilância de síndromes febris agudas", CAAE 0026.0.009.000-07.

\section{References}

[1] Lemos, E.R., Alvarenga, F.B., Cintra, M.L., Ramos, M.C., Paddock, C.D., Ferebee, T.L., et al. (2001) Spotted Fever in Brazil: A Seroepidemiological Study and Description of Clinical Cases in an Endemic Area in the State of São Paulo. The American Journal of Tropical Medicine and Hygiene, 65, 329-334.

[2] Barros e Silva, P.M.R., Pereira, S.C., Fonseca, L.X., Maniglia, F.V.P., Oliveira, S.V. and de Caldas, E.P. (2014) Febre maculosa: uma análise epidemiológica dos registros do sistema de vigilância do Brasil. Scientia Plena, 10, 1-9.

[3] Centro de Vigilância Epidemiológica, Coordenadoria de Controle de Doenças, Secretaria de Estado da Saúde de São Paulo (2012) Febre Maculosa na Região do Grande ABC (Região Metropolitana de São Paulo, Brasil), de 1998 a 2011.Vol. 2.

[4] Centro de Vigilância Epidemiológica, Coordenadoria de Controle de Doenças, Secretaria de Estado da Saúde de São Paulo (2011) Febre Maculosa Brasileira. Suplemento BEPA, 8, 3-31.

[5] Chomel, B.B. and Kasten, R.W. (2010) Bartonellosis, an Increasingly Recognized Zoonosis. Journal of Applied Microbiology, 109, 743-750. http://dx.doi.org/10.1111/j.1365-2672.2010.04679.x

[6] Stützer, B. and Hartmann, K. (2012) Chronic Bartonellosis in Cats: What Are the Potential Implications? Journal of Feline Medicine and Surgery, 14, 612-621. http://dx.doi.org/10.1177/1098612X12458208

[7] Kordick, S.K., Breitschwerdt, E.B., Hegarty, B.C., Southwick, K.L., Colitz, C.M. and Hancock, S.I. (1999) Coinfection with Multiple Tick-Borne Pathogens in a Walker Hound Kennel in North Carolina. Journal of Clinical Microbiology, 37, 2631-2638.

[8] Suksawat, J., Yu, X.J., Hancock, S.I., Hegarty, B.C., Nilkumhang, P. and Breitschwerdt, E.B. (2001) Serologic and Molecular Evidence of Coinfection with Multiple Vector-Borne Pathogens in Dogs from Thailand. Journal of Veterinary Internal Medicine, 15, 453-462. http://dx.doi.org/10.1111/j.1939-1676.2001.tb01574.x

[9] Sofer, S., Gutiérrez, R., Morick, D., Mumcuoglu, K.Y. and Harrus, S. (2015) Molecular Detection of Zoonotic Bartonellae (B. henselae, B. elizabethae and B. rochalimae) in Fleas Collected from Dogs in Israel. Medical and Veterinary Entomology, 29, 344-348. http://dx.doi.org/10.1111/mve.12116

[10] Kumsa, B., Parola, P., Raoult, D. and Socolovschi, C. (2014) Molecular Detection of Rickettsia felis and Bartonella henselae in Dog and Cat Fleas in Central Oromia, Ethiopia. The American Journal of Tropical Medicine and Hygiene, 90, 457-462. http://dx.doi.org/10.4269/ajtmh.13-0010

[11] Fecols, C.C. (1999) The Incidence of Ehrlichial and Rickettsial Infection in Patients with Unexplained Fever and Recent History of Tick Bite in Central North Carolina. The Journal of Infectious Diseases, 180, 900-903. http://dx.doi.org/10.1086/314954

[12] Nascimento, M.M. and Silva, L.J. (2010) Brazilian Spotted Fever: Comparative Evaluation of Indirect Immunofluorescence Assay (IFA) and Polymerasechainreaction (PCR) Methodology in Human Serum Samples from Endemic Areas of São Paulo State. BEPA, Boletim Epidemiológico Paulista (Online), 7, 29-30. 
Submit or recommend next manuscript to SCIRP and we will provide best service for you:

Accepting pre-submission inquiries through Email, Facebook, LinkedIn, Twitter, etc. A wide selection of journals (inclusive of 9 subjects, more than 200 journals)

Providing 24-hour high-quality service

User-friendly online submission system

Fair and swift peer-review system

Efficient typesetting and proofreading procedure

Display of the result of downloads and visits, as well as the number of cited articles

Maximum dissemination of your research work

Submit your manuscript at: http://papersubmission.scirp.org/

Or contactijcm@scirp.org 